\title{
Faktor-Faktor yang Mempengaruhi Terbentuknya Pola Perumahan Leapfrog di Kawasan Peri Urban Kota Malang
}

\author{
Vidya Trisandini Azzizi, Putu Gde Ariastita, ST. MT. \\ Jurusan Perencanaan Wilayah dan Kota, Fakultas Teknik Sipil dan Perencanaan, \\ Institut Teknologi Sepuluh Nopember (ITS) \\ Jl. Arief Rahman Hakim, Surabaya 60111 Indonesia \\ e-mail: ariastita@urplan.its.ac.id
}

\begin{abstract}
Abstrak-Salah satu jenis urban sprawl adalah leapfrog. Perambatan leapfrog merupakan jenis pengembangan yang melompat-lompat, tidak berpola dan tidak memiliki keterkaitan dengan lahan yang sudah terbangun sebelumnya, dan apabila dibiarkan, akan muncul konsekuensi-konsekuensi seperti menambahnya waktu perjalanan dan pencemaran lingkungan. Di Kota Malang, terdapat wilayah-wilayah dengan arahan kawasan pertanian yang memiliki indikasi terjadinya perkembangan leapfrog. Penelitian ini bertujuan untuk mengidentifikasi kawasan-kawasan yang mengalami pola perkembangan leapfrog di kawasan peri urban Kota Malang. Analisis yang digunakan dalam menentukan faktor-faktor yang berpengaruh dalam pembentukan pola perumahan leapfrog adalah confirmatory factor analysis, analytical hierarchy process, weighted overlay, dan buffer analysis. Diketahui bahwa terdapat tiga kriteria yang dapat digunakan untuk menjadi indikator terjadinya leapfrog yakni aksesibilitas, kepadatan penduduk, dan campuran penggunaan lahan (mix-used land) dan perumahan leapfrog di lokasi studi dibagi menjadi perumahan swadaya, yakni perumahan di Jalan Atletik, Jalan Bulu Tangkis, dan Jalan Ikan Tombro Barat, serta perumahan komersial yakni Green View Regency. Diketahui bahwa ada empat indikator yang berpengaruh, yakni ketersediaan infrastruktur pendukung, aksesibilitas, fasilitas umum, serta daya beli masyarakat. Terdapat perbedaan antara jenis rumah swadaya dan jenis rumah komersial, yakni tidak dipertimbangkannya ketersediaan kendaraan umum, biaya transportasi sehari-hari, serta kedekatan dengan fasilitas sekolah dasar bagi masyarakat yang tinggal di tipologi swadaya. Hasil penelitian ini diharapkan bisa menjadi acuan dalam pembuatan peraturan pengendalian perkembangan leapfrog menurut faktorfaktor yang berpengaruh.
\end{abstract}

Kata Kunci-Leapfrog, Peri Urban, Urban sprawl

\section{PENDAHULUAN}

$\mathrm{U}$ RBAN sprawl merupakan fenomena yang sering terjadi dalam perkembangan kota. Urban sprawl merupakan peristiwa yang terjadi apabila jumlah konversi lahan, yang awalnya lahan pertanian, menjadi lahan terbangun, melebihi tingkat pertumbuhan populasi yang ada di wilayah tersebut [1].Terdapat beberapa jenis bentuk spasial urban sprawl, dengan yang paling merugikan adalah bentuk perambatan leapfrog [2]. Jenis pembangunan ini merupakan jenis pengembangan yang melompat-lompat, tidak berpola dan tidak memiliki keterkaitan dengan lahan yang sudah terbangun sebelumnya [3]. Dalam jenis perkembangan ini, penduduk dan penyedia layanan yang tinggal di kawasan leapfrog ini harus melalui lahan kosong saat menempuh jalan dari lahan terbangun satu ke lahan terbangun lainnya [4].

Perkembangan ini berdampak pada semakin meningkatnya biaya pembangunan, karena berbagai infrastruktur penunjang harus dibangun lebih panjang. Selain itu, jarak yang lebih jauh juga menyebabkan waktu perjalanan yang lebih lama ke kawasan perkotaan [5]. Lebih jauh lagi, leapfrog juga memiliki konsekuensi-konsekuensi yang bisa ditemui di jenis perkembangan merambat lainnya, seperti penggunaan alat transportasi yang didominasi oleh kendaraan bermotor, terdapatnya perbedaan antara kemampuan fiskal lokal daerah, serta aksesibilitas jalan yang buruk.

Sebelumnya, telah dilakukan berbagai usaha untuk mengukur terjadinya urban sprawl pada umumnya dan perkembangan leapfrog pada khususnya. Sebagian besar penelitian yang telah dilakukan, dengan beberapa pengecualian seperti milik Galster et al, masih belum dapat mendefinisikan sprawl dan segala kerumitannya. Kepadatan merupakan hal yang cukup mudah untuk diukur, sehingga seringkali, kepadatan dijadikan parameter pengukuran sprawl. Aksesibilitas dapat dijadikan sebagai alat pengukuran terjadinya urban sprawl dengan menggunakan variabel berupa jarak antara kawasan perumahan dengan titik-titik komunitas yang terdiri dari fasilitas-fasilitas umum berupa sekolah, pusat perbelanjaan, rumah sakit, terminal, dan taman. Hal ini dimaksudkan untuk mengukur rata-rata jarak perjalanan ke titik-titik komunitas ini.

Berdasarkan Peraturan Daerah Kota Malang Nomor 4 Tahun 2011 tentang Rencana Tata Ruang Wilayah Kota Malang tahun 2010-2030, kawasan yang menjadi kawasan prioritas pengembangan adalah Kecamatan Kedungkandang di bagian Malang Selatan. Sayangnya, perkembangan paling pesat malah terjadi di bagian Malang Utara, yakni di Kecamatan Lowokwaru yang menurut RTRW Kota Malang 2010-2030 dan Rencana Detil Tata Ruang Kota Malang Utara 2015-2035 justru memiliki arahan sebagai kawasan pertanian karena tanahnya yang relatif subur.

Indikasi leapfrog ini terdapat di beberapa kelurahan di Kecamatan Lowokwaru, Kota Malang, yakni Kelurahan Tunjungsekar, Tunggulwulung, dan Tasikmadu. Ketiga kelurahan yang terletak di bagian paling utara Kota Malang ini 
memiliki akumulasi jumlah penduduk mencapai 28.653 pada tahun 2014, dengan peningkatan jumlah penduduk sebanyak $0,96 \%$ di Kelurahan Tunjungsekar, $1,33 \%$ di Kelurahan Tasikmadu, dan 2,23\% di Kelurahan Tunggulwulung. Jika dirata-rata, angka pertumbuhan di tiga kelurahan ini mencapai angka $1,57 \%$ yang berada di atas rata-rata pertumbuhan Kota Malang yakni sebesar $1,22 \%$.

\section{METODE PENELITIAN}

\section{A. Pendekatan dan Jenis Penelitian}

Pendekatan yang digunakan pada penelitian ini adalah pendekatan rasionalistik. Pendekatan ini dilakukan berdasarkan kebenaran teori secara empiris, yang dibangun berasal dari hasil pengamatan indera dengan didukung landasan teori serta diperlukan proses pemikiran. Di tahapan awal penelitian diketahui permasalahan keberadaan perkembangan leapfrog di kawasan peri urban yang kemudian dibandingkan dengan konsep teori yang berisi alur pemikiran permasalahan yang menjadi latar belakang, fakta empiris, dan teori yang digunakan.

\section{B. Populasi, Sampel dan Metode Pengumpulan Data}

Guna menentukan sampel pada penelitian ini dilakukan dengan teknik purposive sampling dan stratified random sampling. Teknik purposive sampling bertujuan dimana langsung menunjuk responden yang berkompeten atau berpengaruh dalam pencapaian sasaran akhir penelitian. Teknik stratified random sampling digunakan karena populasi yang akan diteliti memiliki karakteristik heterogen dan heterogenitas tersebut memiliki arti yang signifikan pada pencapaian tujuan penelitian. Adapun metode pengumpulan data yang dilakukan terbagi menjadi dua, yakni survey primer berupa kuisioner kepada responden dan survey sekunder berupa tinjauan literatur.

Dalam menentukan ukuran sampel, digunakan teknik sampling probabilistik berupa stratified random sampling, dimana semua anggota populasi memiliki kesempatan yang sama untuk menjadi sampel dalam penelitian. Adapun populasi yang diambil adalah kepala keluarga (KK) yang terdapat di perumahan-perumahan yang teridentifikasi mengalami perkembangan leapfrog, yakni KK yang tinggal di jenis perumahan pertama yakni perumahan jalan atletik, jalan bulutangkis, dan jalan ikan trombo, serta jenis perumahan kedua yakni KK yang tinggal di Green View Regency. Jumlah KK dihitung dari jumlah bangunan permukiman yang ada di masing-masing jenis, dengan asumsi masing-masing rumah dihuni oleh satu KK. yakni:

Adapun metode yang didasarkan pada rumus Slovin,

$$
n=\frac{N}{1+N \alpha^{2}}
$$

Keterangan:

$\mathrm{n}=$ Jumlah sampel

$\mathrm{N}=$ jumlah populasi

$\alpha=$ taraf signifikansi, dalam penelitian ini sebesar $10 \%$
Berdasarkan rumus tersebut, maka sampel dari populasi masing-masing jenis yang akan diambil adalah:

Tabel 1

Pembagian Jumlah Sampel Berdasarkaan Jenis Perumahan

\begin{tabular}{lcc}
\hline \hline \multicolumn{1}{c}{ Jenis } & Jumlah KK & Sampel \\
\hline Rumah Swadaya & 355 & 78 \\
Rumah Komersial & 134 & 55 \\
\hline \hline
\end{tabular}

\section{Metode Analisa}

Teknik analisis yang digunakan dibagi menjadi dua, yakni teknik analisis kualitatif dan kuantitatif. Teknik analisis kuantitatif yang digunakan adalah analisis confirmatory factor analysis, analytical hierarchy process, beserta overlay dengan menggunakan alat bantu berupa GIS. Teknik analisis kualitatif yang digunakan adalah analisis deskriptif.

\section{HASIL DAN DISKUSI}

\section{A. Kriteria yang Dapat Menentukan Perkembangan Perumahan Leapfrog di Kota Malang}

Terdapat tiga kriteria yang dapat digunakan sebagai indikator terjadinya perkembangan leapfrog, dan masing-masing kriteria telah dibobotkan dengan menggunakan analytical hierarchy process. Kriteria-kriteria tersebut yakni:

Kriteria ini sesuai dengan kriteria yang digunakan oleh penelitian-penelitian terdahulu, seperti oleh Ewing, Pendall, dan Chen, Hasse dan Kornbluh, serta Noor, dengan adaptasi yang dilakukan karena data yang tersedia tidak selengkap di

Tabel 2

Kriteria Perumahan Leapfrog di Kota Malang

\begin{tabular}{|c|c|c|}
\hline Variabel & Kriteria & Skor \\
\hline Kepadatan & : Rendah & 0.203 \\
\hline \multirow[t]{2}{*}{ Penduduk } & 500-1249 : Sedang & \\
\hline & 1250-2499 : Tinggi & \\
\hline Campuran & $\leq 2$ landuse $\quad:$ Rendah & 0.349 \\
\hline Penggunaan & 3-4 landuse : Sedang & \\
\hline Lahan & $\geq 5$ landuse $\quad:$ Tinggi & \\
\hline \multirow[t]{4}{*}{ Aksesibilitas } & 750-1500 meter: Bicycle Smart & 0.648 \\
\hline & Growth & \\
\hline & 1500-3000 meter: Suburban Sprawl & \\
\hline & 3000-6000 meter: Rural Sprawl & \\
\hline
\end{tabular}

negara-negara tempat penelitian terdahulu dilakukan. Pembobotan dilakukan dengan menggunakan Analytical Hierarchy Process, dengan aksesibilitas sebagai kriteria berbobot paling tinggi.

B. Penentuan Kawasan Perumahan yang Terindikasi Mengalami Perkembangan Leapfrog di Wilayah Studi

Penentuan kawasan perumahan yang terindikasi mengalami perkembangan leapfrog di wilayah studi dilakukan dengan menggunakan alat analisis weighted overlay pada GIS dengan menggunakan bobot yang sudah didapatkan melalui pembobotan di sasaran sebelumnya. 


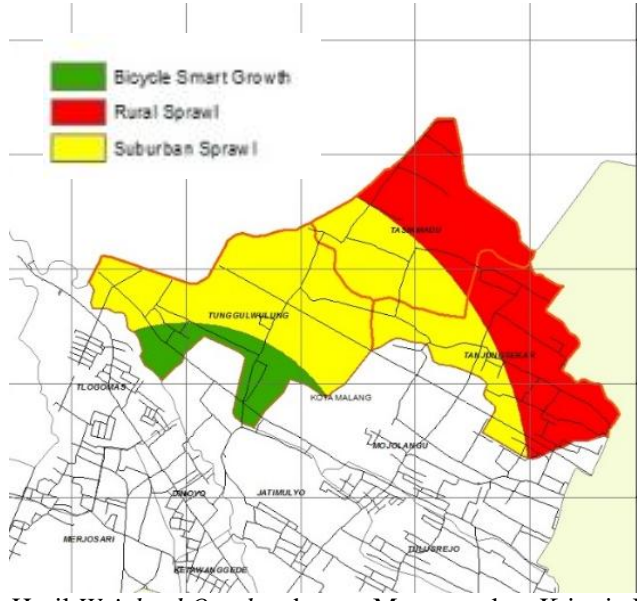

Gambar 1. Hasil Weighted Overlay dengan Menggunakan Kriteria Kepadatan Pednduduk, Campuran Penggunaan Lahan, dan Aksesibilitas

Berdasarkan hasil weighted overlay yang sudah dilaksanakan dengan memperhitungkan tingkatan tiap variabel, diketahui bahwa terdapat dua jenis lokasi, yakni kawasan sprawl dan kawasan non-sprawl. Perumahan yang mengalami perkembangan leapfrog merupakan perumahan yang terletak di kawasan sprawl, dengan jarak antara perumahan tersebut dengan perumahan terdekat di kawasan non-sprawl minimal sama dengan radius suburban sprawl (3000 meter). Kawasan sprawl berada di sebagian Kelurahan Tunggulwulung dan Kelurahan Tasikmadu, sedangkan perumahan yang teridentifikasi mengalami perkembangan leapfrog merupakan kawasan perumahan di ujung Jalan Atletik, perumahan di Jalan Ikan Tombro barat, perumahan di sepanjang Jalan Bulutangkis, dan perumahan Green View Regency.

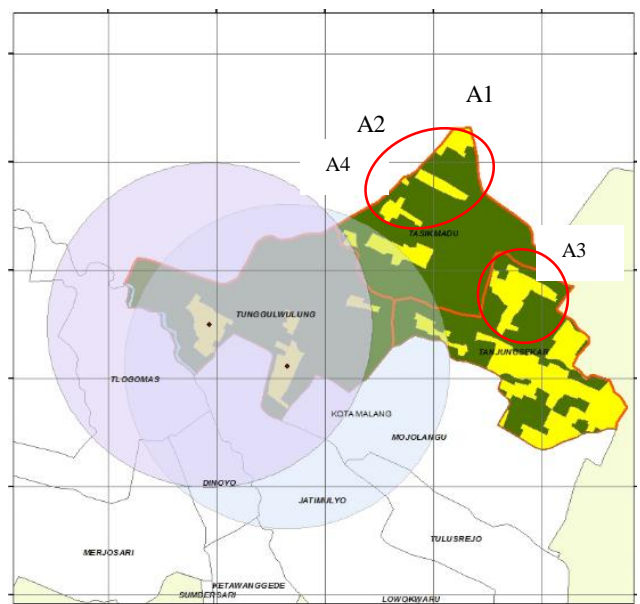

Gambar 2. Hasil Analisis Buffer untuk Menentukan Perumahan Leapfrog

Pembagian jenis perumahan di wilayah studi yang mengalami perkembangan leapfrog didasarkan kepada kesamaan karakteristik geografis, fisik, dan sosial ekonomi masyarakat yang didapatkan dari observasi dan hasil wawancara peneliti.

Perumahan leapfrog di kawasan studi dibagi menjadi dua jenis berdasarkan jenis perumahan yang tercantum di Pasal 21 Undang-undang no. 1 Tahun 2011, yakni berdasarkan pelaku pembangunan dan penghunian, yakni rumah swadaya dan rumah komersial.
Tabel 3

Jenis Perumahan Leapfrog Berdasarkan Pelaku Pembangunan dan Penghunian

\begin{tabular}{cccc}
\hline \hline Nama & Kode & Kondisi & Tipologi/ Jenis \\
Perumahan & & Sosial- & Perumahan (UU \\
& & Ekonomi & $1 / 2011)$ \\
& & Penghuni & \\
\hline $\begin{array}{l}\text { Perumahan Jl. } \\
\text { Atletik }\end{array}$ & A1 & Menengah & $\begin{array}{l}\text { Rumah } \\
\text { Swadaya }\end{array}$
\end{tabular}

Perumahan J1. A2 Menengah Rumah

Bulutangkis Swadaya

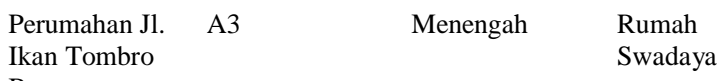

Barat

Green View A4 Menengah Rumah

Regency Komersial

\section{Penentuan Faktor-Faktor yang Menyebabkan Terjadinya Perkembangan Leapfrog di Setiap Jenis Perumahan}

Guna menentukan faktor-faktor yang mempengaruhi terbentuknya perkembangan perumahan leapfrog di lokasi studi, maka digunakan teknik analisa faktor yaitu confirmatory factor analysis (CFA). Teknik analisa tersebut akan mengkonfirmasi faktor - faktor penelitian kepada responden dengan tujuan mereduksi faktor yang tidak layak untuk menjadi faktor terjadinya perkembangan leapfrog.

Tabel 4

Variabel yang Mempengaruhi Terjadinya Perkembangan Leapfrog di Masing-

\begin{tabular}{|c|c|c|c|}
\hline \multicolumn{4}{|c|}{ Masing Perumahan } \\
\hline Indikator & Variabel & Swadaya & Komersial \\
\hline Infrastruktur & Jaringan air & $\sqrt{ }$ & $\sqrt{ }$ \\
\hline \multirow[t]{2}{*}{ Penunjang } & Jaringan telepon & $\sqrt{ }$ & $\sqrt{ }$ \\
\hline & Jaringan drainase & $\sqrt{ }$ & $\sqrt{ }$ \\
\hline \multirow[t]{3}{*}{ Aksesibilitas } & $\begin{array}{l}\text { Ketersediaan } \\
\text { transportasi publik }\end{array}$ & & $\sqrt{ }$ \\
\hline & Jalur pedestrian & $\sqrt{ }$ & $\sqrt{ }$ \\
\hline & $\begin{array}{l}\text { Dekat dengan tempat } \\
\text { kerja }\end{array}$ & $\sqrt{ }$ & $\sqrt{ }$ \\
\hline \multirow[t]{4}{*}{ Fasilitas Umum } & Pemadam kebakaran & & $\sqrt{ }$ \\
\hline & $\begin{array}{l}\text { Tempat Pembuangan } \\
\text { Sampah }\end{array}$ & $\sqrt{ }$ & $\sqrt{ }$ \\
\hline & Sekolah & & $\sqrt{ }$ \\
\hline & Harga lahan & $\sqrt{ }$ & $\sqrt{ }$ \\
\hline Daya beli & $\begin{array}{l}\text { Biaya transportasi } \\
\text { sehari-hari }\end{array}$ & & $\sqrt{ }$ \\
\hline
\end{tabular}

Setelah mengetahui faktor-faktor yang mempengaruhi terjadinya perkembangan perumahan leapfrog, terdapat beberapa temuan selama penelitian dilaksanakan, yakni:

1) Kelurahan-kelurahan yang menjadi lokasi studi kasus adalah pecahan dari Kabupaten Malang, sehingga pada pelaksanaannya, masyarakat setempat cenderung memanfaatkan fasilitas-fasilitas yang ada di Kabupaten Malang karena pusat perkotaan yang ada di Kota Malang berada dalam jarak yang lebih jauh.

2) Masyarakat yang tinggal di permukiman swadaya merupakan masyarakat yang sudah tinggal di kawasan tersebut secara turun temurun, dengan sebagian masih 
berprofesi sebagai petani/buruh tani sehingga memiliki tempat tinggal yang dekat dengan tempat kerja.

3) Faktor yang mempengaruhi terbentuknya perumahan leapfrog yang dibangun pengembang adalah harga lahan, karena pengembang mencari lahan dengan harga paling murah dan dapat dibeli dengan status kepemilikan berupa hak milik.

4) Aksesibilitas merupakan variabel yang membedakan antara jenis perkembangan leapfrog dengan jenis urban sprawl lain yakni ribbon development. Masyarakat dan pengembang yang terlibat dalam ribbon development membeli lahan tersebut karena mementiingkan aksesibilitas yang cepat dengan adanya akses terhadap jalan, sedangkan dalam jenis perkembangan leapfrog, para pemilik unit perumahan tidak mementingkan aksesibilitas asalkan bisa memiliki unit rumah dan lahan dengan harga murah.

\section{KESIMPULAN/RINGKASAN}

Berdasarkan pembahasan yang telah dilakukan, dapat disimpulkan bahwa di Kota Malang bagian Utara telah terjadi perkembangan leapfrog, yakni di Kelurahan Tunggulwulung dan Tasikmadu. Leapfrog yang terjadi di kawasan tersebut dapat dibagi menjadi dua jenis, yakni leapfrog yang dilakukan oleh masyarakat dengan tipe rumah swadaya serta leapfrog yang dilakukan oleh pengembang (rumah komersial). Hal ini ditentukan berdasarkan tiga variabel yakni campuran penggunaan lahan, kepadatan penduduk, serta aksesibilitas kawasan dari titik-titik komunitas yang ada.

Dalam terjadinya perkembangan leapfrog di Kota Malang diketahui bahwa ada empat indikator yang berpengaruh. Indikator tersebut adalah ketersediaan infrastruktur pendukung, aksesibilitas, ketersediaan fasilitas umum, serta daya beli masyarakat. Walaupun indikatornya sama, pada kenyataannya, diketahui bahwa terdapat perbedaan antara tipologi rumah swadaya dan tipologi rumah komersial, yakni:

1) Penduduk di tipologi rumah swadaya tidak mempertimbangkan ketersediaan kendaraan umum dan biaya transportasi sehari-hari sebagai sebagai hal yang penting, karena adanya kecenderungan masyarakat untuk menggunakan kendaraan bermotor milik pribadi.

2) Penduduk di tipologi rumah swadaya tidak mempertimbangkan variabel kedekatan dengan sekolah di Kota Malang sebagai faktor yang penting, karena sebagian masyarakat setempat menyekolahkan anak-anaknya di Kabupaten Malang yang memang memiliki jarak lebih dekat.

Setelah mengetahui faktor-faktor yang berpengaruh dalam pembentukan pola perumahan leapfrog, terdapat beberapa cara pengendalian yang dapat dilaksanakan seperti pemberian insentif dan disinsentif, optimasi penerapan peraturan zonasi, serta penerapan strategi transportation demand management $\mathrm{di}$ wilayah studi.

\section{UCAPAN TERIMA KASIH}

Ucapan terimakasih penulis ucapkan kepada Putu Gde Ariastita ST., MT. selaku dosen pembimbing yang telah memberi masukan, bimbingan serta kritikan yang membangun selama pengerjaan penelitian ini serta kepada narasumber dan pihak-pihak terkait yang telah memberikan waktu dan pikiran untuk penelitian ini.

\section{DAFTAR PUSTAKA}

[1] Simon, D., McGregor, D., \& Nsiah-Gyabaah, K. (2004). The Changing Urban-Rural Interface of African Cities: Definitional Issues and Application to Kumasi, Ghana. Environment and Urbanization, 235-248.

[2] Harvey, R. O., \& Clark, W. A. (1965). The Nature and Economic of Sprawl. Land Economics Vol. 41, 1-9.

[3] Batty, M., Chin, N., \& Besussi, E. (2002). State of the Art Review of Urban Sprawl Impacts and Measurement Techniques. London: Energy, Environment and Sustainable Development Programme European Commission.

[4] Ewing, R., Pendall, R., \& Chen, D. (2002). Measuring Sprawl and Its Impact Volume I. Washington D.C.: Smart Growth America.

[5] Noor, N. M., Asmawi, M. Z., \& Rusni, N. A. (2014). Measuring Urban Sprawl on Geospatial Indices Characterized by Leapfrog Development Using Remote Sensing and GIS. 8th International Symposium of the Digital Earth (pp. 1-6). Kuala Lumpur: IOP Publishing.Bruegmann, R. (2005). Sprawl: A Compact History. Chicago: University of Chicago Press. 